\title{
Spatio-Temporal Variability of Simulated 2 m Air Temperature for Nairobi City, Kenya
}

\author{
Emmanuel Ochola Matsaba1, Ines Langer ${ }^{2 *}$, Aggrey Ochieng Adimo1, \\ John Bosco Mukundi ${ }^{1}$, John Mwibanda Wesonga ${ }^{3}$
}

\author{
${ }^{1}$ Department of Landscape and Environmental Sciences, College of Agriculture and Natural Resources, Jomo Kenyatta University \\ of Agriculture and Technology, Nairobi, Kenya \\ ${ }^{2}$ Institute of Meteorology, Freie Universität, Berlin, Germany \\ ${ }^{3}$ Department of Horticulture and Food Security, College of Agriculture and Natural Resources, Jomo Kenyatta University of \\ Agriculture and Technology, Nairobi, Kenya \\ Email: ocholax@gmail.com, adimo@agr.jkuat.ac.ke,mjbosco@jkuat.ac.ke, \\ ines.langer@met.fu-berlin.de, jwesonga@agr.jkuat.ac.ke, *ines.langer@met.fu-berlin.de
}

How to cite this paper: Matsaba, E. O., Langer, I., Adimo, A. O., Mukundi, J. B., \& Wesonga, J. M. (2020). Spatio-Temporal Variability of Simulated $2 \mathrm{~m}$ Air Temperature for Nairobi City, Kenya. Current $U r$ ban Studies, 8, 205-221.

https://doi.org/10.4236/cus.2020.82011

Received: March 28, 2020

Accepted: May 3, 2020

Published: May 6, 2020

Copyright (c) 2020 by author(s) and Scientific Research Publishing Inc. This work is licensed under the Creative Commons Attribution International License (CC BY 4.0).

http://creativecommons.org/licenses/by/4.0/

\begin{abstract}
Nairobi city in Kenya is an example of the many cities in Africa experiencing rapid growth and too many environmental impacts, including the urban heat islands (UHI) phenomenon. UHI develops and escalates under outrageous hot periods, such as during heatwave, which can affect outdoor microclimate, human thermal comfort, and health and also increase the energy demand for cooling. This study used the MUKLIMO_3 model to reveal the spatial heterogeneity and temporal variability of $2 \mathrm{~m}$ air temperature fields and thermally sensitive areas within Nairobi city. The model reproduced the potential summer day conditions through idealized simulations of temperature, wind, and relative humidity based on the urban topography and local climate zones (LCZs) data at a spatial resolution of $200 \mathrm{~m}$. The aim was to expand knowledge of urban climate change based on the accompanying extensive modification of land use and land cover that are critical for the local-scale atmospheric circulation. The model results revealed intricate spatiotemporal patterns of $2 \mathrm{~m}$ air temperature fields, which accrued from terrain-induced flows and land surface heterogeneity as described by the LCZ parameters. The variation in canopy layer UHI was a joined impact of the unfavorable location of the town and urbanization process, which added to the formation of excessive urban heat load. The study concluded that the enhancement of urban heat load in Nairobi city could be linked to the concept of rapid urbanization process and its historical development. Therefore urban planning strategies such as optimization of mixed building heights and the introduction of green \& blue infrastructure were critical to mitigating heat-stress across
\end{abstract}


Nairobi city.

\section{Keywords}

2 m Air Temperature, MUKLIMO_3 Model, Canopy Layer Urban Heat Island, Land Use Table, Urban Topography, Urban Parameters

\section{Introduction}

Urban climate change is a severe problem for cities around the world (Hashim \& Hashim, 2016), particularly in developing countries like Kenya, where urbanization is happening at a fast rate (Alavipanah, Wegmann et al., 2015). Urbanization prompts changes in the landscape (Oyugi, Odenyo, \& Karanja, 2017), as infrastructure replace vegetation and open land making the surfaces that were once porous and sodden to end up impermeable and dry (Ali, Patnaik, \& Madguni, 2017; Hashim \& Hashim, 2016; Middel et al., 2014; Ren et al., 2016; See et al., 2015; Singh, Kikon, \& Verma, 2017). Tropical cities such as Akure in Nigeria, Cairo in Egypt, and Nairobi city in Kenya are currently experiencing heat waves, and they are expected to face further the challenge of increased intensity, duration, and spatial distribution of heat waves (Connor et al., 2015). The rapid urbanization and increased global warming (Oyugi et al., 2017), led to a sequential of environmental problems (Stone \& Rodgers, 2001), especially the formation of urban heat islands (UHI) (Bechtel \& Daneke, 2012; Stewart \& Oke, 2012) in Nairobi city, a situation whereby urban built-up zones experience hotter temperature than their rural surroundings areas (Santamouris et al., 2017; Stone, Hess, \& Frumkin, 2010; Stone \& Rodgers, 2001) and which is considered to be the most interpretive indication of urban climate change in the current time of increasing urbanization (Santamouris et al., 2007; Santamouris et al., 2017). The changing temperature brought about by the UHI impacts leads to different air qualities, which relate to outdoor microclimate, cooling demands in buildings as well as human thermal comfort levels and health (Bechtel \& Daneke, 2012; Ren et al., 2016; Stone et al., 2010; Vargo, Stone, Habeeb, Liu, \& Russell, 2016). Its (UHI) fundamental drivers are believed to identify with the three attributes of urban areas: increased roughness due to building structural geometries, drier and progressively impenetrable surfaces and anthropogenic warmth and moisture discharges (Bechtel et al., 2015; Bechtel \& Daneke, 2012; Geletič et al., 2018; Stevan et al., 2013).

Climate monitoring for planning and adaptation is gradually becoming an essential element of city planning and development of Nairobi city. However, urban climate change planning and adaptation actions in a city require recognition of the possible range of UHI increase, regarding both its magnitude and spatial distribution that captures the urban footprint analysis, internal structure and 
texture of the urban landscape to answer some critical questions about a rapidly urbanizing city. However, given the diversity of urban structure (Bechtel et al., 2015; Bechtel \& Daneke, 2012; Geletič \& Lehnert, 2016; Lelovics, Unger, Gál, \& Gál, 2014) qualities of relief (Bokva et al., 2014; Bokwa, Hajto, Walawender, \& Szymanowski, 2015; Saaroni \& Ziv, 2010) and the variability of synoptic conditions (Przybylak et al., 2017) it is a relatively complex and challenging task since UHI studies require high range, frequency, quality and density of the measurement network and stations. On the contrary, the contemporary techniques for remote sensing focusing on land surface temperature variability may not provide critical information about $2 \mathrm{~m}$ air temperature (Voogt \& Oke, 2003).

The spatial and temporal variation of the UHI of local cities around the world has been studied frequently (Arnds, Böhner, \& Bechtel, 2017; Arnfield, 2003), as a result of the new development of climate data sources and methodological approaches in recent years, which shifted urban climatology research from identifying UHIs and prediction of UHI intensity to simulating for the exact patterns of the spatiotemporal variability of UHIs and temperature fields in urban environments. Although a large number of UHI studies are available, the results for tropical cities like Nairobi are still missing. During the current progress in exploring the complexity of the process driving the climate system, numerical models designed for application on the city scale have gradually been developed to provide more detailed and more accurate information about the spatiotemporal variability of canopy layer UHI (Bechtel et al., 2017; Ching et al., 2018, 2011; See et al., 2015). The present state of the art of numerical modeling makes it possible to solve the thermodynamics of the atmosphere and complex relations between variables, such as the buildings and vegetation types on the scale of the urban environment (Bechtel et al., 2015; Bechtel \& Daneke, 2012; Sun, 2013). The thermodynamic version of microscale urban climate MUKLIMO_3 model (in German, Mikroskalige Urbane Klima Modell ) developed by Deutscher Wetterdienst (2014), is designed for urban climate studies especially on issues of urban land use planning and the climatic effects of local land-use changes as well as for analyzing the climate of entire cities.

This study focused on the MUKLIMO_3 model to simulate and identify Spatio-temporal variability of $2 \mathrm{~m}$ air temperature for a typical summer (warmest) day conditions in Nairobi City and its surroundings. The study applied the concept of topography and local climate zones (LCZs) to obtain representative spatial units for analyses of $2 \mathrm{~m}$ air temperature differences between various types of urban neighborhoods (Alexander \& Mills, 2014; Bokwa et al., 2015; Geletič et al., 2016). The aim was to expand knowledge of urban climate change and to document the canopy UHI phenomenon for Nairobi city. MUKLIMO_3 results can be used to assess human thermal stress utilizing the perceived temperature. The study was borne out of the need to inform city planners and policymakers to manage the heat load in the city. 


\section{Materials and Methods}

\subsection{Description of the Study Area}

Nairobi city longitude $36.6^{\circ}$ and latitude $-1.1^{\circ}$ (upper left corner) and longitude $37.1^{\circ}$ and latitude $-1.5^{\circ}$ (lower right corner) and altitude of $1684 \mathrm{~m}$ above sea level (Oyugi et al., 2017), is the largest and capital city of Kenya, with a populace of 4.40 million in 2019 census (Figure 1).

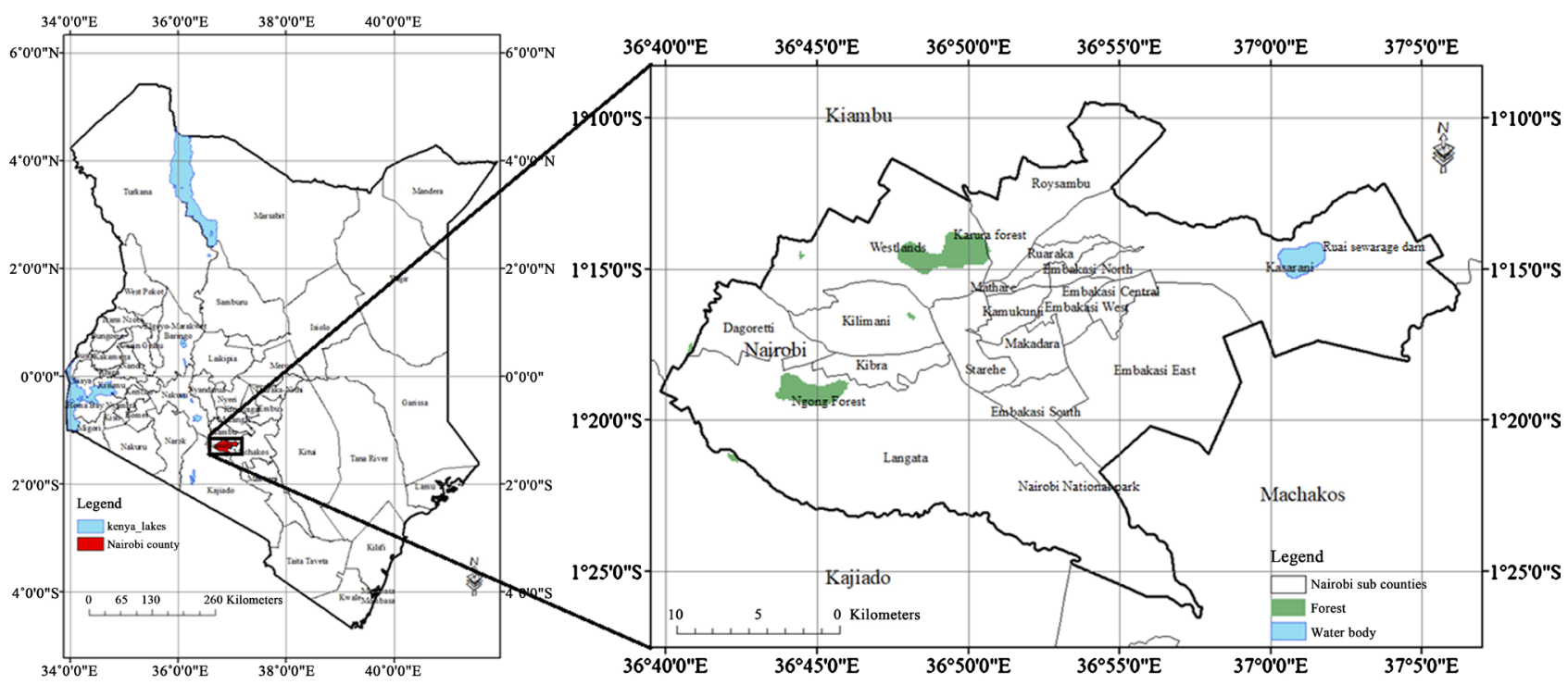

Figure 1. The location of Nairobi city.

The city started as a railway town in 1899 with an initial city plan which covered $18 \mathrm{~km}^{2}$ and later extended to $25 \mathrm{~km}^{2}$ in 1920 . The city plan completely ignored Asian laborers and Africans, which resulted in informal housing, began being built on the perimeter of the cities. The city has grown in concentric zones, clearly-defined historical centres, industrial areas, old and new residential buildings, housing estates, modern shopping centres, and malls with allotments. With functionalism as the central principle, Nairobi was classified into zones that led to a neighborhood with irregular, as well as regular street plans. There is a presence of an exceptionally polluted stream (the Nairobi River) and a greater extent of open low plant vegetated spaces. The natural landscape outside the city centre is prevalently natural, with agriculture areas on the Western and sand and uncovered soils on the Eastern part. Patches of LCZs A-dense trees B-scattered trees, and C-bush scrub complete the scene mosaics of the city (Ochola et al., 2020).

\subsection{Simulation of $2 \mathrm{~m}$ Air Temperature Using MUKLIMO_3 Model}

The thermodynamic version of the microscale urban climate MUKLIMO_3 model included prognostic equations for atmospheric temperature, relative humidity, wind speed, and wind direction (Früh et al., 2011). MUKLIMO_3 model was employed on the urban scale to simulate the $2 \mathrm{~m}$ air temperature field, relative humidity field, and wind field for Nairobi city and its surroundings on a three-dimensional (3D) model 
grid. The MUKLIMO_3 model provided the best radiation-driven climatic conditions that were characterized by an almost clear sky (Bokva et al., 2014; Hollosi \& Zuvela-aloise, 2017) as conceptualized in Figure 2 below.

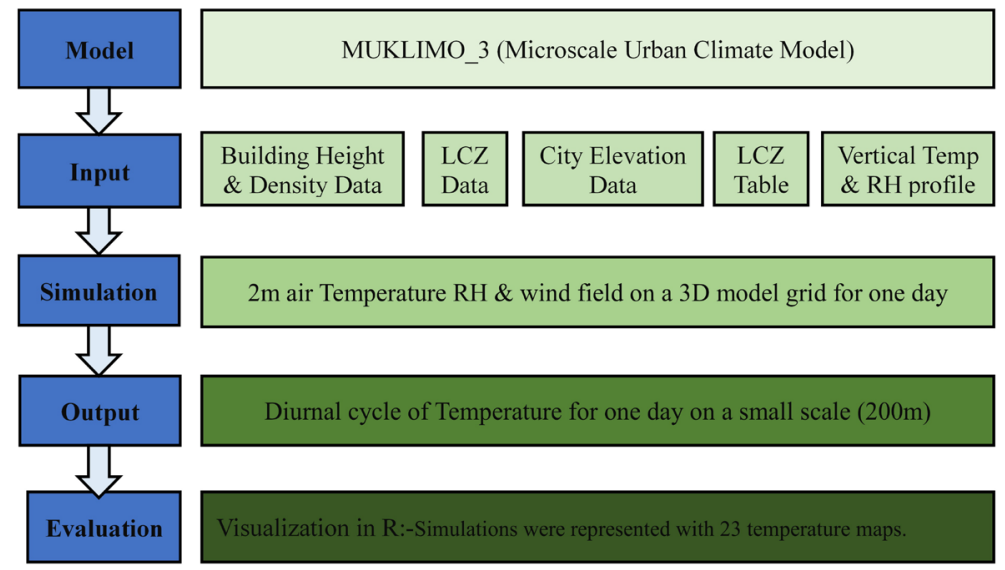

Figure 2. Conception framework of the MUKULIMO_3 model. Source: own conceptualization.

The $2 \mathrm{~m}$ air temperature field for the potential warmest day (26th February 2018) condition was reproduced through idealized simulations of temperature, wind, and relative humidity in Nairobi city based on the city's topography and LCZs data (Ochola et al., 2020) at a spatial resolution of $200 \mathrm{~m}$. The model used LCZ data (Land use file) to describe the urban land use classes and unique thermal surfaces within Nairobi city (Figure 3 ).

Topographical data (elevation file) was used to describe the influence of city

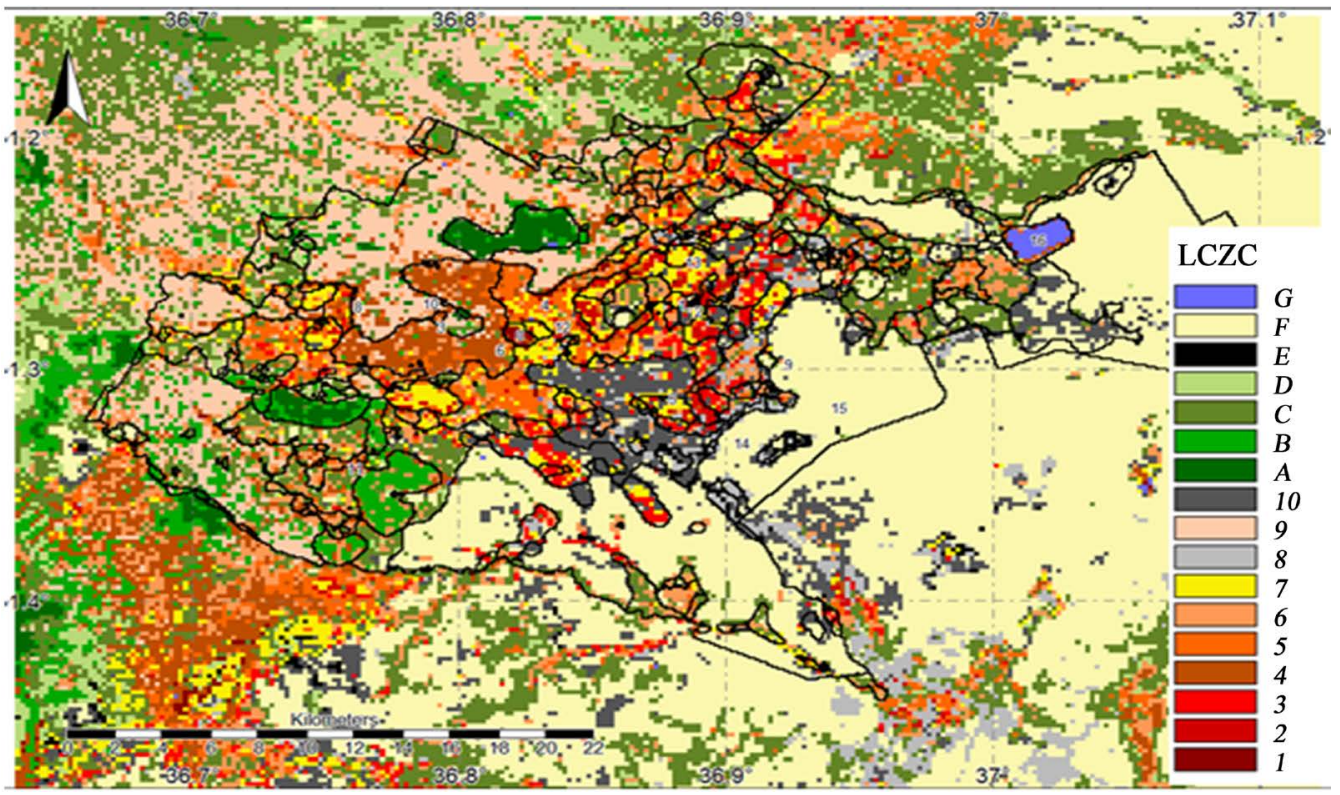

Figure 3. Spatial distribution of LCZs in Nairobi. Key: 1-compact high-rise, 2-compact mid-rise, 3-compact low-rise, 4-open high-rise, 5-open mid-rise, 6-open low-rise, 7-lightweight low-rise, 8-large low-rise, 9-sparsely built-up, 10-heavy industry, A-dense trees, B-scattered trees, C—bush, scrub, D-low plants, E-bare rock or paved, F-bare soil or sand; G-water. 
location and topology on the urban heat load within the city and its environment (Figure 4).

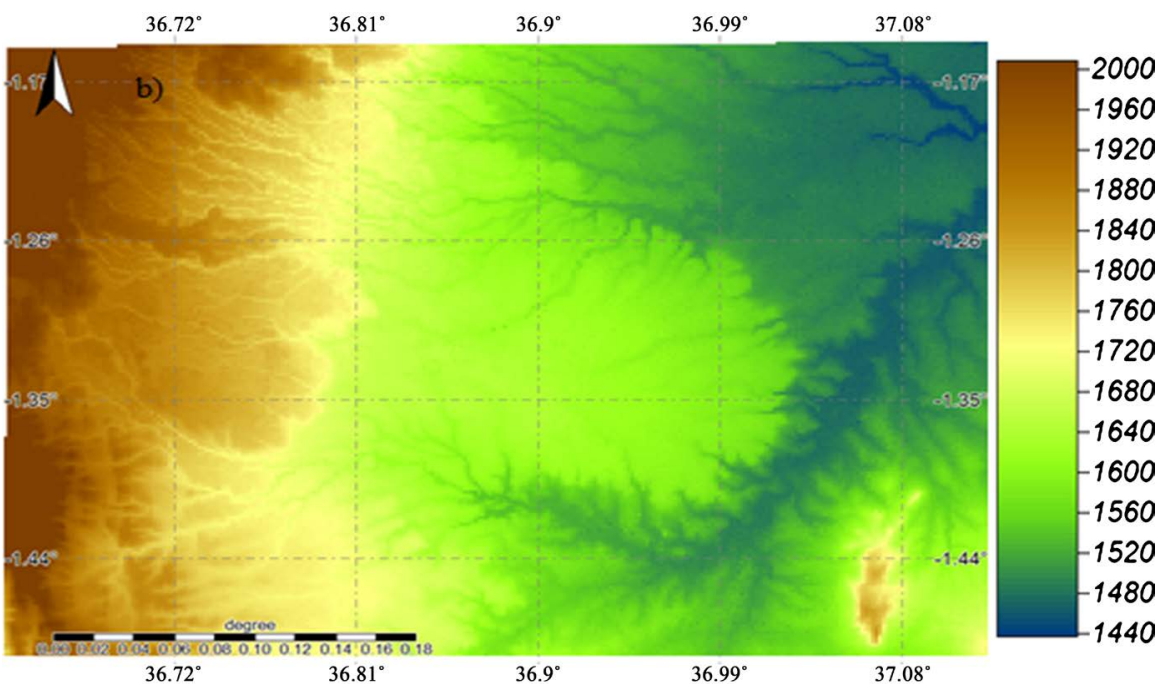

Figure 4. Spatial distribution of topographic elevation (in meters) of Nairobi.

The five layers of meteorological data (air temperature, relative humidity, and speed of wind) in the vertical profile of the atmosphere (up to $3142 \mathrm{~m}$ above ground level) for the operation of the MUKLIMO_3 model was derived from the sounding data of $63741 \mathrm{HKNC}$ Nairobi (Nairobi Dagoreti weather station located at latitude $-1.300587^{\circ}$ and longitude $36.759368^{\circ}$ ) observations at $00 \mathrm{Z} 28$ February 2018 (Table 1).

Table 1. The vertical profile of the atmosphere shows various layers of temperature simulations in the Muklimo_3 model (source: Wyoming Weather Web-University of Wyoming).

\begin{tabular}{cccccc}
\hline Parameter/layers & $\mathbf{1}$ & $\mathbf{2}$ & $\mathbf{3}$ & $\mathbf{4}$ & $\mathbf{5}$ \\
\hline Height above sea level $(\mathrm{m})$ & 1798 & 2106 & 2420 & 2920 & 3142 \\
Temperature $\left({ }^{\circ} \mathrm{C}\right)$ & 18.8 & 17.2 & 14.5 & 10.2 & 8.8 \\
Relative Humidity $(\%)$ & 56 & 68 & 77 & 95 & 92 \\
\hline
\end{tabular}

One Dimension (1D) vertical atmospheric profile of time-varying atmospheric conditions (Temperature, relative humidity, and wind speed) at the Nairobi Dagoreti weather referent station was the initial boundary conditions. The 15-layered soil model and the 3-layered vegetation model were then introduced (Bokva et al., 2014; Bokwa et al., 2015). Land use classes were defined by LCZs according to the land use table (LU_Table) describing LCZ properties and urban structures characterized by a set of parameters for each LCZ class. The structural building properties inside a grid cell were depicted by three measurable parameters (Building fraction, Wall area index, Mean building height) to represent the interactions between the unresolved building structures and the environment (Bokwa et al., 2015). 
MUKLIMO_3 model is a non-hydrostatic microscale model with z-coordinates (Geletič \& Lehnert, 2016), which solves the Reynolds-averaged Navier-Stokes equations to simulate atmospheric flow fields in the presence of unresolved buildings (Früh et al., 2011). The model considered the friction impacts of building structures and turbulence generated because of wind stream separation to calculate turbulent fluxes of heat, moisture and momentum (Hollosi \& Zuvela-aloise, 2017; Žuvela-Aloise, 2017; Žuvela-Aloise, Koch, Buchholz, \& Früh, 2016) at ground level, the walls and the roofs of buildings in a domain with unresolved build-up, is described in Früh et al., 2011 (Geleti, Lehnert, Dobrovolný, \& Bulletin, 2016). The model also considered the effects of cloud cover on radiation. However, it did not include cloud processes, precipitation, horizontal runoff, or anthropogenic heat sources. The vegetation in the canopy model has three vertical layers: tree crown, tree trunk, and low vegetation (Hollosi \& Zuvela-aloise, 2017; Žuvela-Aloise et al., 2016) (Table 2).

Table 2. Parameterization of the unresolved buildings in MUKLIMO_3 model for LCZs: building fraction $\left(\gamma_{b}\right)$, mean building height $\left(h_{b}\right)$, wall area index $\left(w_{b}\right)$, fraction of pavement $(v)$, fraction of tree crown canopy $\left(\sigma_{t}\right)$, fraction of low vegetation $\left(\sigma_{c}\right)$, tree height $\left(h_{t}\right)$, height of the low vegetation $\left(h_{c}\right)$, surface albedo of materials (Alb). The fractions $\gamma_{b}$ and $\sigma_{t}$ are relative to the total grid cell area $(200 \mathrm{~m} * 200 \mathrm{~m})$. The fraction $\mathrm{v}$ is relative to the area without buildings and trees, and $\sigma_{c}$ is relative to the remaining surface. LCZ Key: see Figure 2 (Ochola et al., 2020).

\begin{tabular}{|c|c|c|c|c|c|c|c|c|c|c|c|c|c|c|}
\hline $\mathrm{LCZ}$ & $y_{b}$ & $h_{b}$ & $w_{b}$ & $\boldsymbol{V}$ & $z_{0}$ & $h_{t}$ & $p_{t}$ & $h_{s}$ & $p_{s}$ & $h_{c}$ & $L A I_{c}$ & $\sigma_{t}$ & $\sigma_{v}$ & Alb \\
\hline LCZ 1 & 0.50 & 80.0 & 29.25 & 0.35 & 0.20 & 0.00 & 0.00 & 0.00 & 0.00 & 0.50 & 1.00 & 0.08 & 0.70 & 0.11 \\
\hline LCZ 2 & 0.50 & 25.0 & 10.53 & 0.28 & 0.20 & 0.00 & 0.00 & 0.00 & 0.00 & 0.50 & 1.00 & 0.07 & 0.70 & 0.13 \\
\hline LCZ 3 & 0.49 & 10.0 & 4.49 & 0.25 & 0.20 & 0.00 & 0.00 & 0.00 & 0.00 & 0.50 & 1.00 & 0.08 & 0.70 & 0.15 \\
\hline LCZ 4 & 0.39 & 80.0 & 29.25 & 0.31 & 0.20 & 0.00 & 0.70 & 8.00 & 0.05 & 0.50 & 1.00 & 0.22 & 0.70 & 0.13 \\
\hline LCZ 5 & 0.30 & 25.0 & 10.53 & 0.31 & 0.20 & 0.00 & 0.70 & 8.00 & 0.05 & 0.50 & 1.00 & 0.27 & 0.70 & 0.14 \\
\hline LCZ 6 & 0.30 & 10.0 & 2.80 & 0.30 & 0.20 & 0.00 & 0.70 & 8.00 & 0.05 & 0.50 & 1.00 & 0.22 & 0.70 & 0.14 \\
\hline LCZ 7 & 0.90 & 4.00 & 1.50 & 0.05 & 0.20 & 0.00 & 0.00 & 0.00 & 0.00 & 0.50 & 1.00 & 0.01 & 0.70 & 0.14 \\
\hline LCZ 8 & 0.40 & 10.00 & 1.50 & 0.45 & 0.20 & 0.00 & 0.70 & 8.00 & 0.05 & 0.50 & 1.00 & 0.07 & 0.70 & 0.16 \\
\hline LCZ 9 & 0.12 & 8.50 & 2.88 & 0.25 & 0.20 & 0.00 & 0.70 & 8.00 & 0.05 & 0.50 & 1.00 & 0.41 & 0.70 & 0.13 \\
\hline LCZ A & 0.00 & 0.00 & 0.00 & 0.00 & 0.20 & 30.0 & 0.30 & 8.00 & 0.05 & 0.50 & 0.50 & 1.00 & 0.50 & 0.11 \\
\hline LCZ B & 0.00 & 0.00 & 0.00 & 0.00 & 0.20 & 15.0 & 0.70 & 8.00 & 0.05 & 0.50 & 0.50 & 0.20 & 0.50 & 0.12 \\
\hline LCZ C & 0.00 & 0.00 & 0.00 & 0.00 & 0.30 & 2.00 & 0.7 & 8.00 & 0.05 & 0.50 & 1.50 & 0.20 & 0.90 & 0.14 \\
\hline LCZ D & 0.00 & 0.00 & 0.00 & 0.02 & 0.30 & 0.30 & 0.00 & 0.00 & 0.00 & 0.30 & 1.50 & 0.20 & 0.80 & 0.16 \\
\hline LCZ E & 0.00 & 0.00 & 0.00 & 0.95 & 0.03 & 0.00 & 0.00 & 0.00 & 0.00 & 0.20 & 0.50 & 0.00 & 0.40 & 0.17 \\
\hline LCZ F & 0.00 & 0.00 & 0.00 & 0.00 & 0.10 & 0.00 & 0.00 & 0.00 & 0.00 & 0.30 & 1.00 & 0.00 & 0.90 & 0.15 \\
\hline LCZ G & 0.00 & 0.00 & 0.00 & -1.00 & 0.001 & 0.00 & 0.00 & 0.00 & 0.00 & 0.20 & 1.00 & 0.00 & 0.00 & 0.16 \\
\hline
\end{tabular}

\section{Results}

The model simulations were represented with 24 temperature maps at a horizontal resolution of $200 \mathrm{~m}$. The time step between two successive modeled fields 
was 60 minutes. The results indicated a complex spatial structure of the simulated $2 \mathrm{~m}$ air temperature and urban heat load in Nairobi City. The minimum day time simulated $2 \mathrm{~m}$ air temperature, and maximum nighttime simulated 2 $\mathrm{m} 2 \mathrm{~m}$ air temperature was found in densely built-up LCZs in the city center and residential areas with flat terrain north-east of Nairobi city. Lower $2 \mathrm{~m}$ air temperature early in the morning was typical of Natural LCZ types, while the warmer $2 \mathrm{~m}$ air temperature was typical of built-up LCZ types. The places with the lowest air temperature in the early morning hours before sunrise was located in areas dominated with the featureless landscape of soil or sand cover with few or no plants (LCZ F) in the southeastern (Mlolongo, Syiokimau, Athi River and some parts of Emabakasi) parts of Nairobi (Figure 5: $2 \mathrm{~m}$ air temperature for Nairobi at 06 am to $08 \mathrm{am}$ ). After the sunrise, lower $2 \mathrm{~m}$ air temperature is typical to natural landscapes with forests, scattered trees, bushes, low plants, and water bodies (LCZs A, B, and G).

In comparison, warmer $2 \mathrm{~m}$ air temperature are typical to both open and high-density built-up areas very large low rise and heavy industrial buildings (LCZs 1 - 10), and open natural with bushes and scrubs, low plants (mostly grasslands, agricultural fields, and parks), and paved allotment areas, and bare soils and sand (LCZs C, D, E, and F) (Figure 5 and Figure 6: $2 \mathrm{~m}$ air temperature for Nairobi from 09 am to $05 \mathrm{pm}$ ). As the air gets warmer (from 11 am to 05 pm), the model gradually generates areas with a higher proportion of LCZ 2, 3, $7,8,9$, and 10 that are warmer than their surroundings, including areas located outside the compact urban development. However, the distinct UHI is not formed until noon to $03 \mathrm{pm}$. At $03 \mathrm{pm}$, the UHI is formed over most of the city center.

After the sunset, the distribution of the $2 \mathrm{~m}$ air temperature was predominantly influenced by the spatial distribution of wind fields within LCZs. Areas with lower temperature were located in high-density built-up areas very large low rise and heavy industrial buildings (LCZs 1 - 10) (Figure 6 and Figure 7: 2 $\mathrm{m}$ air temperature for Nairobi at $06 \mathrm{pm}$ to $05 \mathrm{am})$. In comparison, the warmer air temperature was located in build-up LCZ types. As the air gets colder (at 06 pm to $05 \mathrm{pm}$ ), the model gradually generated areas with a lower proportion of hot spots ( build-up areas) that are warmer than their surroundings, including areas located outside the compact urban development. The distinct nocturnal UHI formed only in built-up areas of the city center and reduced gradually after the sunset. Hotspots within the city were formed in areas with a higher proportion of high-density built-up classes (LCZ 2, 3, 7 and 10), with $2 \mathrm{~m}$ air temperature range of $30^{\circ} \mathrm{C}$ to $40^{\circ} \mathrm{C}$ during daytime and $28^{\circ} \mathrm{C}$ to $34^{\circ} \mathrm{C}$ at night. On the contrary, relatively cooler spots within the city correspond to larger areas of LCZ $\mathrm{A}, \mathrm{B}$, and $\mathrm{G}$ during the daytime where $2 \mathrm{~m}$ air temperature reached $20^{\circ} \mathrm{C}, \mathrm{LCZ}$ $\mathrm{A}, \mathrm{B}, \mathrm{C}, \mathrm{D}, \mathrm{F}$ and $\mathrm{G}$ during night time where air temperature reaches about $18^{\circ} \mathrm{C}$ at $04 \mathrm{am}$. The lowest temperature predicted for forested areas (LCZ A) in the city center was about $25^{\circ} \mathrm{C}$. Thus the model simulated temperature differences of 


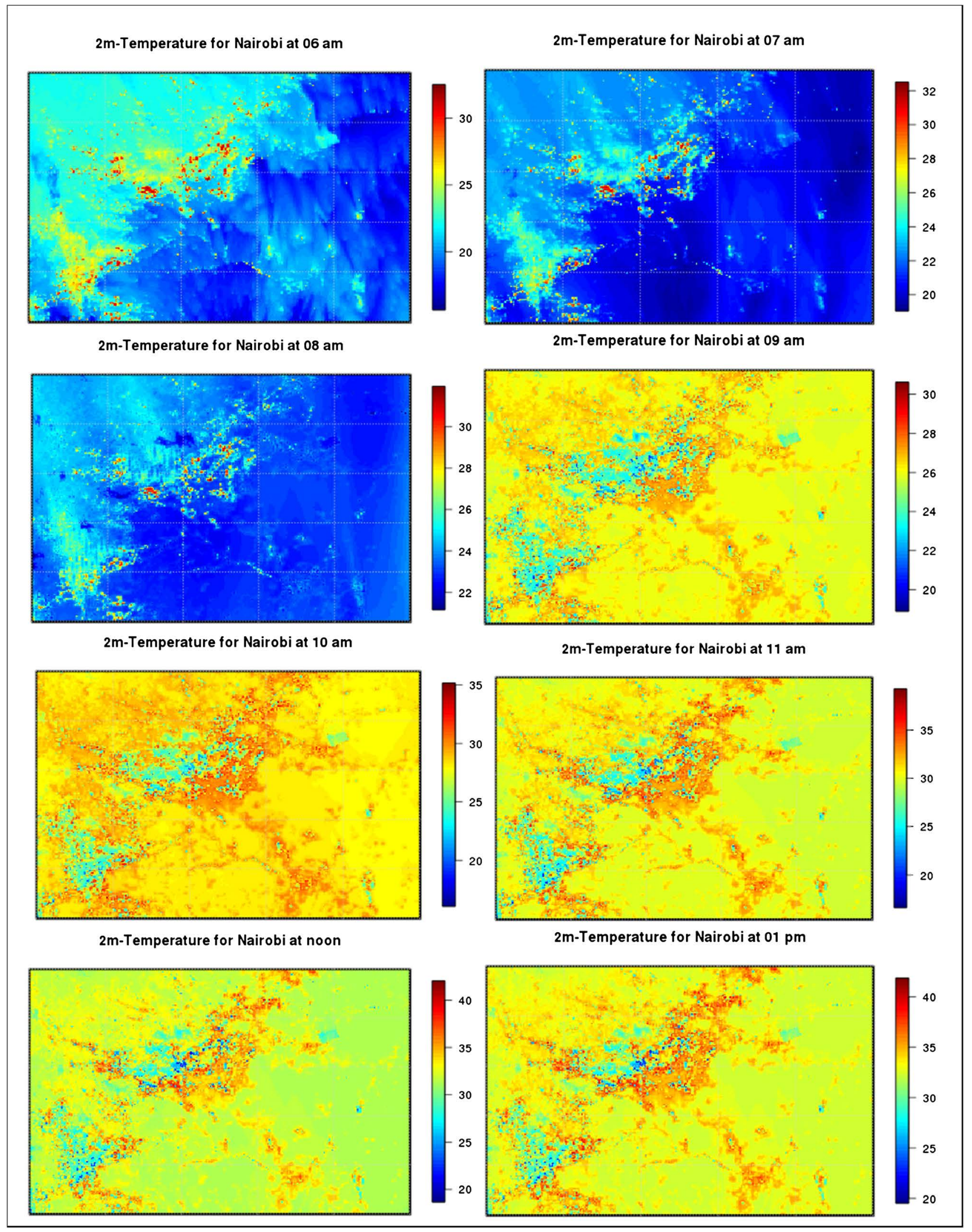

Figure 5. Hourly simulated spatial and temporal $(06 \mathrm{am}-01 \mathrm{pm})$ variability of the $2 \mathrm{~m}$ air temperature $\left({ }^{\circ} \mathrm{C}\right)$ in Nairobi city for $26^{\text {th }}$ February 2018. 


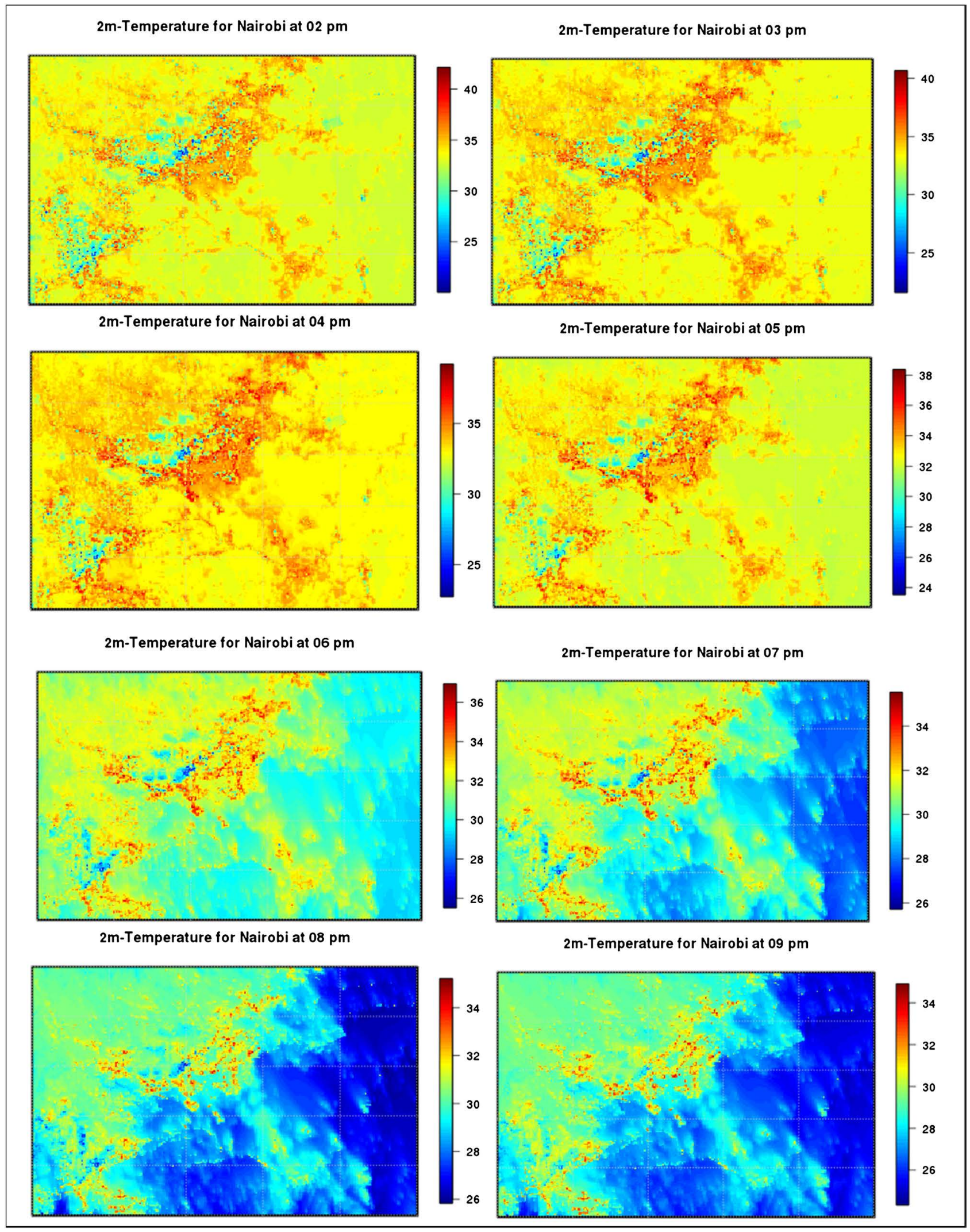

Figure 6. Hourly simulated spatial and temporal $(02 \mathrm{pm}-09 \mathrm{pm})$ variability of the $2 \mathrm{~m}$ air temperature $\left({ }^{\circ} \mathrm{C}\right)$ in Nairobi city for $26^{\text {th }}$ February 2018. 


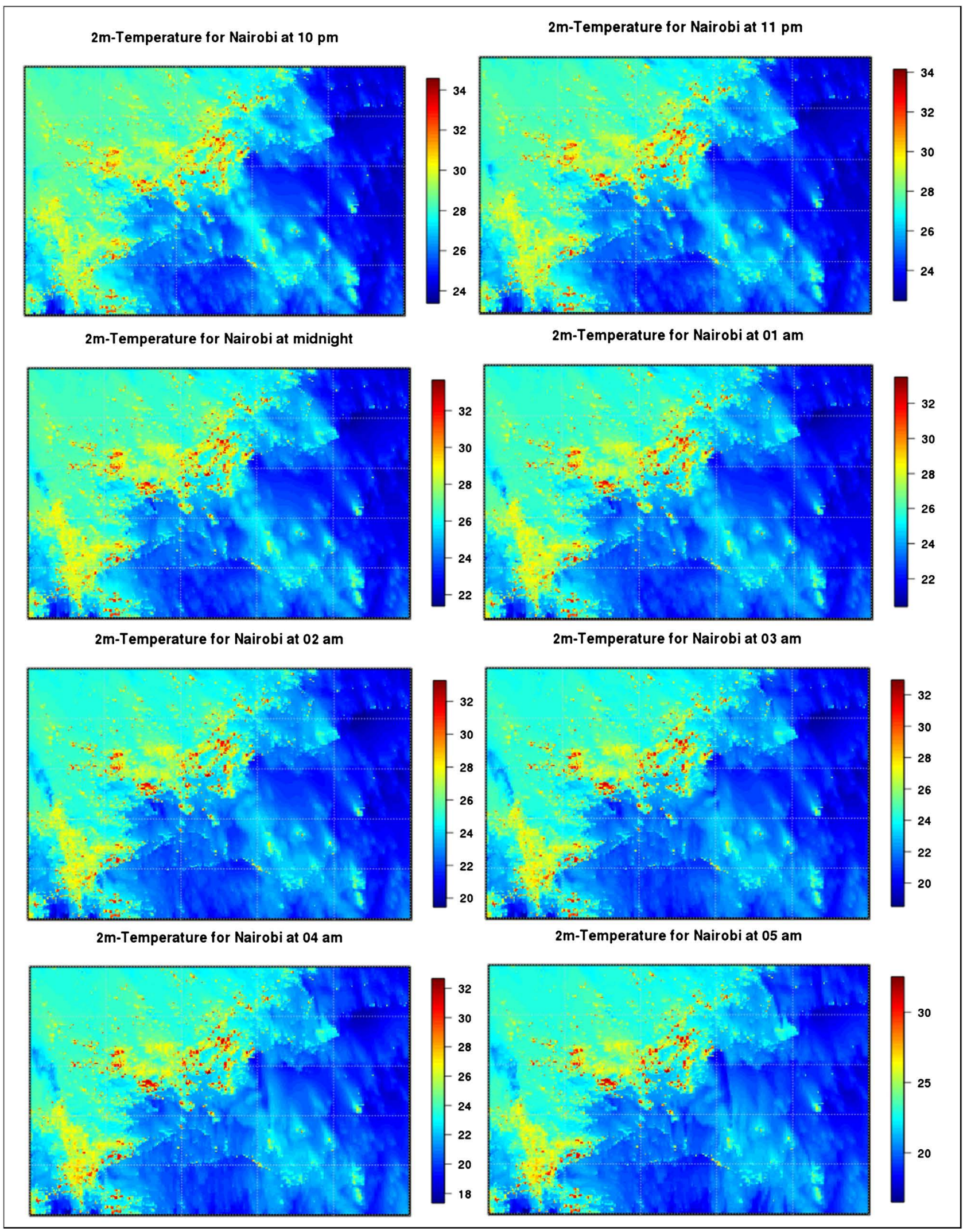

Figure 7. Hourly simulated spatial and temporal $(10 \mathrm{pm}-05 \mathrm{am})$ variability of the $2 \mathrm{~m}$ air temperature $\left({ }^{\circ} \mathrm{C}\right)$ in Nairobi city for $26^{\text {th }}$ February 2018. 
up to $15^{\circ} \mathrm{C}$ between the warmest part of the city and the most cooling forests at 1200 noon to 03 pm (Figure 5 and Figure 6). The model, however, forecasts a relatively higher intensity of canopy layer UHI during the evening and night hours. At 9 p.m., the warmest parts of the city are only about $12^{\circ} \mathrm{C}$ warmer than the natural landscape around the city (predominantly LCZ D) and up to $10^{\circ} \mathrm{C}$ warmer than the forested areas.

In summary, the MUKLIMO_3 model output revealed intricate spatial and temporal patterns of $2 \mathrm{~m}$ air temperature fields across Nairobi city and its environment. High-density built-up areas of the city recorded possible maximum urban cooling during the daytime and maximum urban heating patterns at night compared to areas that were sparsely built or covered with vegetations. The spatial pattern of simulated $2 \mathrm{~m}$ air temperature confirmed the presence of canopy layer UHI across Nairobi city. The variation in simulated warmer $2 \mathrm{~m}$ air temperature in parts of the town accrued from terrain-induced flows and land surface heterogeneity as described by the LCZ parameters.

\section{Discussion}

February 26, 2018, was considered in this study because it was a typical summer day having recorded the hottest temperature with maximum thermal stress within the city. The model results confirmed the presence of hotspots in the city both daytime and night time, especially in high-density built-up areas of the city with a high percentage of water-resistant, non-reflective surfaces and low vegetation compared to the surrounding rural areas with urban green spaces. Spatial analysis of simulated of $2 \mathrm{~m}$ temperature fields and the increase of heat load in the high-density built-up areas demonstrated canopy layer UHI in Nairobi city as a joined impact of both terrain (for example, terrain sheltering and the unfavorable location of the city), or local land surface heating (due to a high percentage of water-resistant, non-reflective surfaces, building structure type and density, a high fraction of asphalt and a small amount of vegetation cover) which add to the formation of excessive urban heat load.

During the day, the heat load in high altitude vegetated areas was locally reduced compared to the lowland high built-up areas, which are visible in the vertical profile of temperature (Table 1) due to the temperature inversion, which makes the elevated and natural areas warmer. The location of the city and the building type, consisting of high density, a high fraction of pavement, and a small amount of vegetation, contributed to the formation of excessive heat load at night. During the night, robust and reliable cooling of the free surface results in a temperature inversion, and therefore MUKLIMO_3 model assumed a temperature that was just $1^{\circ} \mathrm{C}$ higher in the high-density built-up areas than in the rural natural surroundings and temperature that was about $10^{\circ} \mathrm{C}$ higher in the built-up areas than in the coldest forests.

MUKLIMO_3 model primarily reflected the effect of elevation and land cover on UHI distribution evident during the daytime and at night. The model pre- 
dicts globally higher temperature at lower elevations. It can be considered as a simplification (Bokva et al., 2014; Bokwa et al., 2015). On the other hand, the model did not reflect the extent of the variability of building density (i.e., the amount and effect of accumulated heat). It is anticipated that for more accurate simulation of the spatiotemporal temperature field, it is necessary to focus attention on the LCZ table.

Moreover, it is possible that the concept of LCZ is too general for modeling on a detailed level and may have caused incorrect settings of the thermal capacity of individual surfaces. However, the use of LCZ classes to describe urban features decreased model uncertainties related to the choice of selection by limiting and standardizing the parameterization of the unresolved buildings in the MUKLIMO_3 model. Generally, the MUKLIMO_3 model considered not only the physical features of the unresolved urban structure but also the elevation and advection of the air masses between the surrounding surfaces computing atmospheric processes in the urban condition. The heat load for an entire individual city relied upon, relief, the surrounding land use types, and location in the city.

The comparison of the real station measurements and MUKLIMO_3 simulations in Nairobi city and its surroundings was not possible because of a lack of access to the hourly $2 \mathrm{~m}$ air temperature data from the metrological stations. However, the model prediction was consistent and, therefore, could correspond best with the situation on 28 February 2018 (see Figures 5-7); this may be related to more stable atmospheric conditions very close to climatological warm days. However, Individual problems with the accuracy of the model simulation could be primarily related to the starting phase of the modeling (at $10.00 \mathrm{am}$, and 11.00 am; see Figure 5). Additionally, the MUKLIMO_3 model should be used to simulate future projections of the UHI phenomenon and create spatial configurations of planting designs with more cooling and fewer energy demands and their application to the whole in Nairobi city.

\section{Conclusion}

MUKLIMO_3 model was used to reproduce a simplified urban structure and indicate both spatial and temporal variability in $2 \mathrm{~m}$ air temperature for a potential summer day in Nairobi city. Simulation results showed complex spatial and temporal patterns of $2 \mathrm{~m}$ air temperature fields, which confirmed the presence of canopy layer UHI. The variations in simulated $2 \mathrm{~m}$ air temperature patterns accrued from terrain-induced flows and land surface heterogeneity, as described by the urban parameters. Therefore, the enhancement of urban heat load in Nairobi city could be linked to the concept of rapid urbanization process and its historical development. Hence urban planning strategies such as optimization of mixed building heights and the introduction of green \& blue infrastructure were critical to mitigating heat-stress across Nairobi city. The results were the first to provide the relationship between LCZs and the spatial distribution of UHI for 
Nairobi city using the MUKLIMO_3 model. The model outputs could be used to study the development of urban microclimates within Nairobi city. The results could also be useful for evaluating the influence of location, urban parameters, and weather conditions on urban microclimatic within Nairobi city. However, the MUKLIMO_3 model must be validated for Nairobi city to reach a better performance. Therefore, there will be further studies to understand the model settings and optimal input data preparations.

\section{Acknowledgements}

The project leading to this publication has received support from the the European Union's Seventh Framework Programme for research, technological development and demonstration under grant agreement no 266603, ERAfrica LOCLIM_3 project. The authors acknowledge the support of the Freie Universität Berlin, Prof. Uwe Ulbrich. The authors thank Stephen Waringo Waweru for proofreading this manuscript. The authors thank USGS (U.S. Geological Survey) for the free data availability and SAGA GIS and Google Earth pro Developers for the free software. Special thanks to the LCZ scheme developers for giving their advice on applying the LCZ scheme and adopting the WUDAPT method in this study and Deutscher Wetterdienst who developed MUKLIMO_3 model.

\section{Conflicts of Interest}

The authors declare no conflicts of interest regarding the publication of this paper.

\section{References}

Alavipanah, S., Wegmann, M., Qureshi, S., Weng, Q., \& Koellner, T. (2015). The Role of Vegetation in Mitigating Urban Land Surface Temperature: A Case Study of Munich, Germany during the Warm Season. Sustainability (Switzerland), 7, 4689-4706. https://doi.org/10.3390/su7044689

Alexander, P. J., \& Mills, G. (2014). Local Climate Classification and Dublin's Urban Heat Island. Atmosphere, 5, 755-774. https://doi.org/10.3390/atmos5040755

Ali, S. B., Patnaik, S., \& Madguni, O. (2017). Microclimate Land Surface Temperature across Urban Land Use/Land Cover Forms. Global Journal of Environmental Science and Management, 3, 231-242.

Arnds, D., Böhner, J., \& Bechtel, B. (2017). Spatio-Temporal Variance and Meteorological Drivers of the Urban Heat Island in a European City. Theoretical and Applied Climatology, 128, 43-61. https://doi.org/10.1007/s00704-015-1687-4

Arnfield, A. J. (2003). Two Decades of Urban Climate Research: A Review of Turbulence, Exchanges of Energy and Water, and the Urban Heat Island. International Journal of Climatology, 23, 1-26. https://doi.org/10.1002/joc.859

Bechtel, B., \& Daneke, C. (2012). Classification of Local Climate Zones Based on Multiple Earth Observation Data. IEEE Journal of Selected Topics in Applied Earth Observations and Remote Sensing, 5, 1191-1202. https://doi.org/10.1109/JSTARS.2012.2189873

Bechtel, B., Alexander, P., Böhner, J., Ching, J., Conrad, O., Feddema, J., Stewart, I. et al. 
(2015). Mapping Local Climate Zones for a Worldwide Database of the Form and Function of Cities. ISPRS International Journal of Geo-Information, 4, 199-219. https://doi.org/10.3390/ijgi4010199

Bechtel, B., Demuzere, M., Sismanidis, P., Fenner, D., Brousse, O., Beck, C., Verdonck, M.-L. et al. (2017). Quality of Crowdsourced Data on Urban Morphology-The Human Influence Experiment (HUMINEX). Urban Science, 1, 15. https://doi.org/10.3390/urbansci1020015

Bokva, A., Dobrovolny, P., Gál, T., Geletic, J., Gulyás, Á., Hajtó, M., Zuvela-Aloise, M. et al. (2014). Modelling the Impact of Climate Change on Heat Load Increase in Central European Cities. In 9th International Conference on Urban Climate Jointly with 12th Symposium on the Urban Environment (pp. 6-10).

http://real.mtak.hu/28567/1/CCMA2-5-3151332_a.pdf

Bokwa, A., Hajto, M. J., Walawender, J. P., \& Szymanowski, M. (2015). Influence of Diversified Relief on the Urban Heat Island in the City of Kraków, Poland. Theoretical and Applied Climatology, 122, 365-382. https://doi.org/10.1007/s00704-015-1577-9

Ching, J., Mills, G., Bechtel, B., See, L., Feddema, J., Wang, X., Theeuwesits, N. et al. (2018). WUDAPT: An Urban Weather, Climate, and Environmental Modeling Infrastructure for the Anthropocene. Bulletin of the American Meteorological Society, 99, 1907-1924. https://doi.org/10.1175/BAMS-D-16-0236.1

Ching, J., See, L., Ren, C., Masson, V., Hildalgo, J., Wang, X., Feddema, J. et al. (2011). The Wudapt Framework for Generating Urban Morphology, Material Composition and Activity Data for Modeling (pp. 1-6).

Connor, O., Fatima, M. De, Bechtel, B., Foley, M., Mills, G., Ching, J., Gál, T. et al. (2015). CENSUS of Cities: LCZ Classification of Cities (Level 0)-Workflow and Initial Results from Various Cities. In ICUC9 (pp. 8-13). Toulouse.

https://doi.org/10.13140/RG.2.1.4028.5206

Früh, B., Becker, P., Deutschländer, T., Hessel, J.-D., Kossmann, M., Mieskes, I., Wienert, U. et al. (2011). Estimation of Climate-Change Impacts on the Urban Heat Load Using an Urban Climate Model and Regional Climate Projections. Journal of Applied Meteorology and Climatology, 50, 167-184. https://doi.org/10.1175/2010JAMC2377.1

Geleti, J. Č., Lehnert, M., Dobrovolný, P., \& Bulletin, H. G. (2016). Modelled Spatio-Temporal Variability of Air Temperature in an Urban Climate and Its Validation: A Case Study of Brno, Czech Republic. Hungarian Geographical Bulletin, 65, 169-180. https://doi.org/10.15201/hungeobull.65.2.7

Geletič, J., \& Lehnert, M. (2016). GIS-Based Delineation of Local Climate Zones: The Case of Medium-Sized Central European Cities. Moravian Geographical Reports, 24, 2-12. https://doi.org/10.1515/mgr-2016-0012

Geletič, J., Lehnert, M., Dobrovolný, P., Geleti, J., Lehnert, M., Dobrovolný, P., Dobrovolný, P. et al. (2016). Land Surface Temperature Differences within Local Climate Zones, Based on Two Central European Cities. Remote Sensing, 8, 1-18. https://doi.org/10.3390/rs8100788

Geletič, J., Lehnert, M., Savić, S., Milošević, D., Geleti, J., Lehnert, M., Milo, D. et al. (2018). Modelled Spatiotemporal Variability of Outdoor Thermal Comfort in Local Climate Zones of the City of Brno, Czech Republic. Science of the Total Environment, 624, 385-395. https://doi.org/10.1016/j.scitotenv.2017.12.076

Hashim, J. H., \& Hashim, Z. (2016). Climate Change, Extreme Weather Events, and Human Health Implications in the Asia Pacific Region. Asia Pacific Journal of Public Health, 28, 8S-14S. https://doi.org/10.1177/1010539515599030 
Hollosi, B., \& Zuvela-aloise, M. (2017). Urban Climate Model MUKLIMO_3 in Prediction Mode-Evaluation of Model Performance Based on the Case Study of Vienna. Geophysical Research Abstracts, 19, EGU2017-16455.

Lelovics, E., Unger, J., Gál, T., \& Gál, C. V. C. V. (2014). Design of an Urban Monitoring Network Based on Local Climate Zone Mapping and Temperature Pattern Modelling. Climate Research, 60, 51-62. https://doi.org/10.3354/cr01220

Middel, A., Häb, K., Brazel, A. J., Martin, C. A., \& Guhathakurta, S. (2014). Impact of Urban Form and Design on Mid-Afternoon Microclimate in Phoenix Local Climate Zones. Landscape and Urban Planning, 122, 16-28. https://doi.org/10.1016/j.landurbplan.2013.11.004

Ochola, E. M., Fakharizadehshirazi, E., Adimo, A. O., Mukundi, J. B., Wesonga, J. M., \& Sodoudi, S. (2020). Inter-Local Climate Zone Differentiation of Land Surface Temperature for Management of Urban Heat in Nairobi City, Kenya. Urban Climate, 31, Article ID: 100540. https://doi.org/10.1016/j.uclim.2019.100540

Oyugi, M. O., Odenyo, V. A. O., \& Karanja, F. N. (2017). The Implications of Land Use and Land Cover Dynamics on the Environmental Quality of Nairobi City, Kenya. American Journal of Geographic Information System, 6, 111-127.

Przybylak, R., Uscka-Kowalkowska, J., Araźny, A., Kejna, M., Kunz, M., \& Maszewski, R. (2017). Spatial Distribution of Air Temperature in Torun (Central Poland) and Its Causes. Theoretical and Applied Climatology, 127, 441-463. https://doi.org/10.1007/s00704-015-1644-2

Ren, C., Cai, M., Wang, M., Xu, Y., \& Ng, E. (2016). Local Climate Zone (LCZ) Classification Using the World Urban Database and Access Portal Tools (WUDAPT) Method: A Case Study in Wuhan and Hangzhou. In The Fourth International Conference on Countermeasure to Urban Heat Islands (4th IC2UHI) (pp. 1-12).

Saaroni, H., \& Ziv, B. (2010). Estimating the Urban Heat Island Contribution to Urban and Rural Air Temperature Differences over Complex Terrain: Application to an Arid City. Journal of Applied Meteorology and Climatology, 49, 2159-2166. https://doi.org/10.1175/2010JAMC2473.1

Santamouris, M., Paraponiaris, K., \& Mihalakakou, G. (2007). Estimating the Ecological Footprint of the Heat Island Effect over Athens, Greece. Climatic Change, 80, 265-276. https://doi.org/10.1007/s10584-006-9128-0

Santamouris, M., Haddad, S., Fiorito, F., Osmond, P., Ding, L., Prasad, D., Wang, R. et al. (2017). Urban Heat Island and Overheating Characteristics in Sydney, Australia. An Analysis of Multiyear Measurements. Sustainability, 9, 712. https://doi.org/10.3390/su9050712

See, L., Ching, J., Masson, V., Mills, G., Neophytou, M., Connor, M. O., Bechtel, B. et al. (2015). Generating WUDAPT's Specific Scale-Dependent Urban Modelling of Level 1 and Level 2 Data: The Need for WUDAPT.

Singh, P., Kikon, N., \& Verma, P. (2017). Impact of Land Use Change and Urbanization on Urban Heat Island in Lucknow City, Central India. A Remote Sensing Based Estimate. Sustainable Cities and Society, 32, 100-114.

https://doi.org/10.1016/j.scs.2017.02.018

Stevan, S., Dragan, M., Lazar, L., Vladimir, M., Daniela, A., \& Dragoslav, P. (2013). Classifying Urban Meteorological Stations Sites by "Local Climate Zones": Preliminary Results for the City of Novi Sad (Serbia). Geographica Pannonica, 17, 60-68. https://doi.org/10.5937/GeoPan1303060S

Stewart, I. D., \& Oke, T. R. (2012). Local Climate Zones for Urban Temperature Studies. 
Bulletin of the American Meteorological Society, 93, 1879-1900. https://doi.org/10.1175/BAMS-D-11-00019.1

Stone, B., \& Rodgers, M. O. (2001). Urban Form and Thermal Efficiency: How the Design of Cities Influences the Urban Heat Island Effect. Journal of the American Planning Association, 67, 186-198. https://doi.org/10.1080/01944360108976228

Stone, B., Hess, J. J., \& Frumkin, H. (2010). Urban Form and Extreme Heat Events: Are Sprawling Cities More Vulnerable to Climate Change Than Compact Cities? Environmental Health Perspectives, 118, 1425-1428. https://doi.org/10.1289/ehp.0901879

Sun, X. (2013). Comparative Analysis of Urban Morphology: Evaluating Space Syntax and Traditional Morphological Methods (pp. 1-54).

Vargo, J., Stone, B., Habeeb, D., Liu, P., \& Russell, A. (2016). The Social and Spatial Distribution of Temperature-Related Health Impacts from Urban Heat Island Reduction Policies. Environmental Science \& Policy, 66, 366-374.

https://doi.org/10.1016/j.envsci.2016.08.012

Voogt, J., \& Oke, T. (2003). Thermal Remote Sensing of Urban Climates. Remote Sensing of Environment, 86, 370-384. https://doi.org/10.1016/S0034-4257(03)00079-8

Žuvela-Aloise, M. (2017). Enhancement of Urban Heat Load through Social Inequalities on an Example of a Fictional City King's Landing. International Journal of Biometeorology, 61, 527-539. https://doi.org/10.1007/s00484-016-1230-Z

Žuvela-Aloise, M., Koch, R., Buchholz, S., \& Früh, B. (2016). Modelling the Potential of Green and Blue Infrastructure to Reduce Urban Heat Load in the City of Vienna. Climatic Change, 135, 425-438. https://doi.org/10.1007/s10584-016-1596-2 